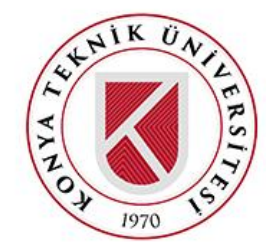

Konya Mühendislik Bilimleri Dergisi, c. 10, s. 1, 189-199, 2022

Konya Journal of Engineering Sciences, v. 10, n. 1, 189-199, 2022

ISSN: 2667-8055 (Electronic)

DOI: 10.36306/konjes.1039091

\title{
EFFICIENT AND SELECTIVE ANTITUMOR AGENTS BASED ON CATIONIC CALIXARENES: SYNTHESIS, CHARACTERIZATION, AND ANTIPROLIFERATIVE PROPERTIES
}

\author{
Mehmet OGUZ \\ Selcuk University, Department of Chemistry, Konya, TÜRKIYYE \\ moguz@selcuk.edu.tr
}

(Geliş/Received: 20.12.2021; Kabul/Accepted in Revised Form: 07.02.2022)

\begin{abstract}
Research work on the preparation of anti-tumor agents with active properties is still a major field for the pharmaceutical industry to promote more potent anticancer drugs to the market. However, one of the main disadvantages of current and future anticancer drugs is selectivity. Therefore, in recent decades, a new perspective has to be developed for chemotherapy, such as "targeted" drugs and minimal side effects. Calixarenes, composed of phenolic units linked by methylene bridges are versatile kinds of macrocyclic compounds in supramolecular chemistry that can be modified to hydrophilic and hydrophobic cavities. The biocompatibility of calixarene derivatives allows them to be used in the development of in vivo and in vitro applications. For this reason, the calixarenes with different active groups, have been synthesized by many researchers as a target structure, and their biological activities and in particular their anti-cancer properties, have been studied. The purpose of the current study is to synthesize calix[4]arene derivatives bearing the cationic group at the lower rim and investigation their cytotoxic effect for several cancerous cells. Results demonstrated that calix[4]arene derivative having 5-bromopenty trimethylammonium bromide moieties (CN) and calix[4]arene derivative having 3-bromopropyl-triphenylphosphonium bromide moieties $(\mathbf{C P})$ compounds selectively inhibits proliferation of A549 (13.42 $\mu \mathrm{M})$ and HeLa (17.05 $\mu \mathrm{M})$ and Hep-2 cells $(>200$ $\mu \mathrm{M}$ and $162.71 \mu \mathrm{M})$, respectively.
\end{abstract}

Keywords: Supramolecule, Calixarene, Cytotoxicity, Cationic, Anticancer Agent

\section{Katyonik Kaliksarenlere Dayalı Etkili ve Seçici Antitümör Ajanlar: Sentez, Karakterizasyon ve Antiproliferatif Özellikler}

ÖZ: Aktif özelliklere sahip anti-tümör ajanların hazırlanmasına yönelik araştırma çalışmaları, farmasötik endüstrisinin piyasaya daha güçlü antikanser ilaçları tanıtması için hala önemli bir alandır. Bununla birlikte, mevcut ve gelecekteki antikanser ilaçlarının ana dezavantajlarından biri seçiciliktir. Bu nedenle, son yıllarda kemoterapi için "hedeflenen" ilaçlar ve minimal yan etkiler gibi yeni bir bakış açısı geliştirilmelidir. Metilen köprüleriyle bağlı fenolik birimlerden oluşan kaliksarenler, supramoleküler kimyada hidrofilik ve hidrofobik boşluklara dönüştürülebilen çok yönlü makrosiklik bileşiklerdir. Kaliksaren türevlerinin biyouyumluluğu, in vivo ve in vitro uygulamaların geliştirilmesinde kullanılmalarına izin verir. Bu nedenle farklı aktif gruplara sahip kaliksarenler birçok araştırmacı tarafından hedef yapı olarak sentezlenmiş ve biyolojik aktiviteleri ve özellikle kanser önleyici özellikleri incelenmiştir. Bu çalışmanın amacı, alt kenarda katyonik grubu taşıyan kaliks[4]aren türevlerini sentezlemek ve çeşitli kanserli hücreler için sitotoksik etkilerini araştırmaktır. Sonuçlar, CN ve CP bileşiklerinin sırasıyla A549 (13.42 uM) ve HeLa (17.05 uM) ve Hep-2 hücrelerinin (>200 uM ve $162.71 \mathrm{uM}$ ) proliferasyonunu seçici olarak engellediğini gösterdi.

Anahtar Kelimeler: Supramolekül, Kaliksaren, Sitotoksisite, Katyonik, Antikanser Ajan 


\section{INTRODUCTION}

Cancer, i.e., uncontrolled growth of abnormal cells, is the second leading cause of death in the world after cardiovascular diseases (Siegel et al., 2019). Pharmaceutical industries throughout the world produce many anticancer agents, most of them have negative side effects, and they cannot distinguish selectively tumor cells from healthy cells. To overcome this situation, efforts are made by different scientists and they are working mainly on hybrid molecules containing two or more pharmacophores' groups that can selectively target tumor cells without effecting healthy cells (Geraci et al.., 2008; Pur, 2016). Moreover, supramolecular chemistry has provided a more sophisticated solution in the form of macrocyclic compounds such as calixarenes. Calix[n]arene are third-generation supramolecular class with eclectic applications after cyclodextrin and crown ethers. They are synthesized by base catalyzed condensation of para-substituted phenol and formaldehyde. They are consists of central annulus phenolic rings connected by methylene units, at the lower part hydroxyl groups and a hydrophobic cavity on the upper rim (Akceylan et al., 2021; Cengel ve Farabi, 2021; Consoli et al., 2015; Oguz et al., 2020; Oguz et al., 2020; Oguz et al., 2020; Oguz et al., 2021; Ozcelik, Farabi ve Tabakci, 2019). Calixarenes have excellent flexible structural properties that can be modified according to its application. Recently, calixarenes have been proven to be good building scaffolds for the synthesis of anticancer agents in the literature (Rouge et al., 2010; Nimse ve Kim, 2013; Santos et al., 2015; Yousaf et al., 2015; Naseer et al., 2017; Yilmaz et al., 2020; An et al., 2021; Zhou et al., 2021). Due to their multiple derivatization possibilities, different functional groups that have anti-tumor properties can easily be incorporated at their lower/upper rim (de Fátima et al, 2009; Rodik et al., 2009; Dings et al., 2013; Saluja ve Sekhon, 2013; Läppchen et al., 2015; Yousaf et al., 2015; An et al., 2016; An et al., 2019; Rego ve ark., 2019).

Here, based on all of the above considerations, we have focused on synthesizing two cationic groupbearing calix[4]arene derivatives to investigate their anticancer activity in different human cancer cell lines and human healthy epithelial cell line.

\section{EXPERIMENTAL SECTION}

\subsection{Methods, Materials and Instruments}

All chemicals and solvents used in the experimental studies were supplied as the analytical grade from various commercial companies like Merck and Sigma-Aldrich. Infrared spectra (FT-IR) measurements were performed using a Vertex 70 (ATR) instrument spectrometer. Varian (400 MHz) instrument was used NMR measurements ( ${ }^{1} \mathrm{H}$ and ${ }^{13} \mathrm{C}$ NMR) of both $\mathbf{C N}$ and $\mathbf{C P}$ in deuterated solvents.

\subsection{Synthesis of Compound $\mathrm{CP}$}

The compound $\mathbf{C P}$ has been synthesized according to the literature with some modifications (Sayin ve Yilmaz, 2017). A mixture of $p$-tert-butylcalix[4]arene (C) $(0.75 \mathrm{~g}, 1.15 \mathrm{mmol})$ and (3-bromopropyl)triphenylphosphonium bromide $(1.21 \mathrm{~g}$, $3.25 \mathrm{mmol})$ in acetone $(30 \mathrm{~mL})$ was refluxed in the presence of $\mathrm{K}_{2} \mathrm{CO}_{3}(0.27 \mathrm{~g}$, $2.87 \mathrm{mmol}$ ) for $36 \mathrm{~h}$. The reaction was checked with TLC until compound $\mathrm{C}$ disappeared. The excess of the solvent was evaporated in a vacuum and the remaining product was extracted with chloroform/ $\mathrm{H}_{2} \mathrm{O}$. The chloroform phase was dried with anhydrous magnesium sulfate. The target product (CP) was obtained as a white solid (yield: 88\%). ${ }^{1} \mathrm{H}-\mathrm{NMR}\left(400 \mathrm{MHz}, \mathrm{CDCl}_{3}\right)$ : 1.08 (s, 18H, t-butyl), 1.54 (s, 18H, $t$-butyl), 2.53 (s, 4H, $\left.\mathrm{CH}_{2}\right), 3.32\left(\mathrm{~d}, 4 \mathrm{H}, \mathrm{J}=13.2 \mathrm{~Hz}, \mathrm{Ar}-\mathrm{CH}_{2}-\mathrm{Ar}\right), 4.22\left(\mathrm{~d}, 4 \mathrm{H}, \mathrm{J}=13.3 \mathrm{~Hz}, \mathrm{Ar}-\mathrm{CH}_{2}-\mathrm{Ar}\right), 4.47-4.47\left(\mathrm{~m}, 8 \mathrm{H},-\mathrm{CH}_{2}\right), 6.77(\mathrm{~s}$, 2H, ArOH), 6.84 (s, 4H, ArH), 7.52 (s, 4H, ArH), 7.91-8.14 (m, 30H, ArH). ${ }^{13} \mathrm{C}-\mathrm{NMR}\left(100 \mathrm{MHz}, \mathrm{CDCl}_{3}\right): 17.5$, 22.2, 31.2, 31.9, 33.7, 34.1, 34.3, 75.0, 118.1, 119.0, 125.9, 127.6, 130.8, 132.9, 134.0, 135.4, 135.6, 142.1, 147.5, 149.1, 150.3 . 


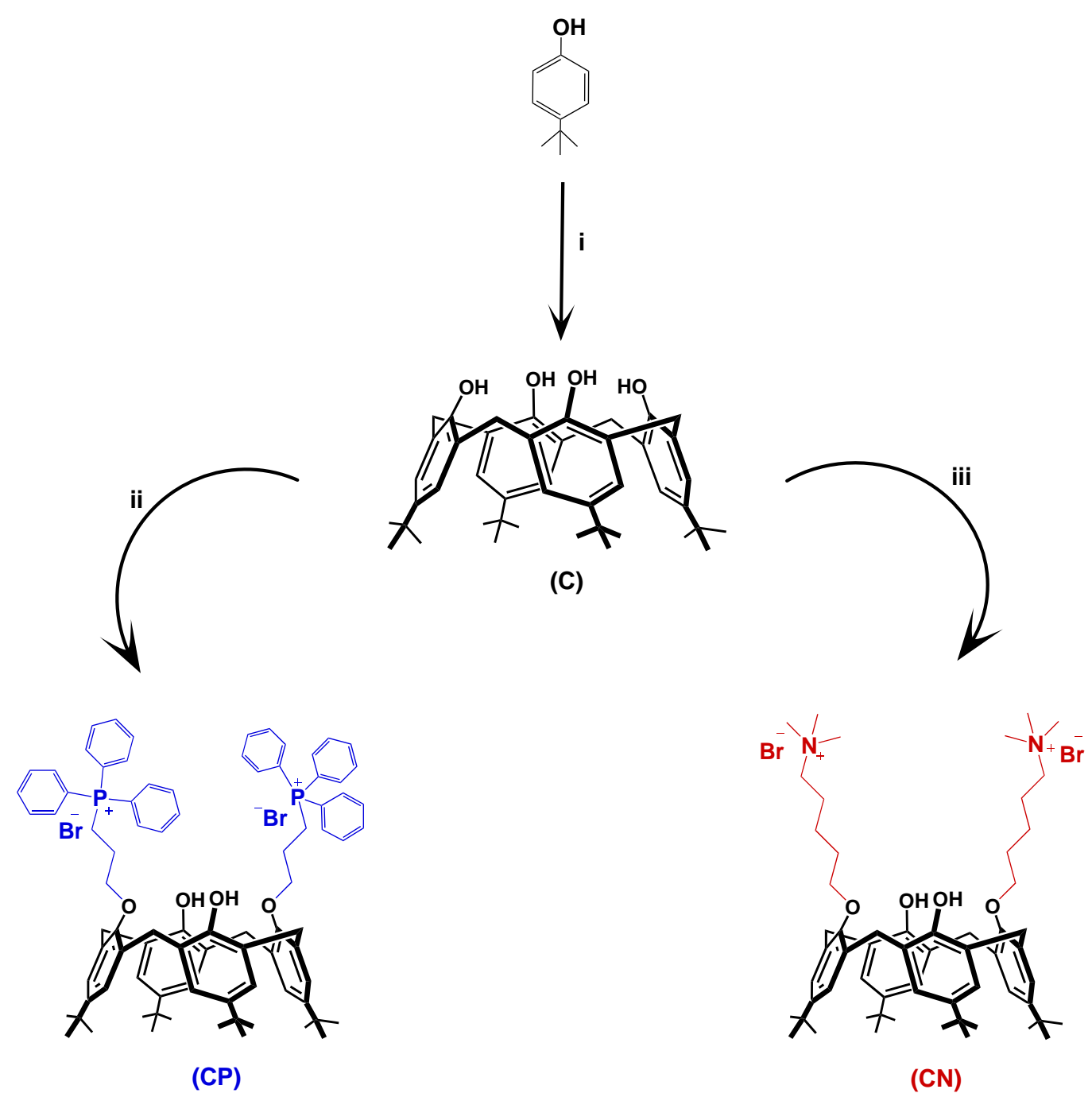

Figure 1. The synthesis pathway for the preparation of $\mathbf{C P}$ and $\mathbf{C N}$. Reaction conditions: (i) $\mathrm{HCHO}, \mathrm{NaOH}$; (ii) $\mathrm{K}_{2} \mathrm{CO}_{3}$, acetone, 3-bromopropyl-triphenyl-phosphonium bromide; (iii) $\mathrm{K}_{2} \mathrm{CO}_{3}$, acetone, 5-bromopentyltrimethylammonium bromide.

\subsection{Synthesis of Compound CN}

The compound $\mathbf{C N}$ was synthesized with some modifications according to the previous method (Sayin ve Yilmaz, 2017). In acetone (30 $\mathrm{mL}), \quad p$-tert-butylcalix[4]arene $(\mathbf{C}) \quad(0.75 \mathrm{~g}, 1.56 \mathrm{mmol})$, (5bromopentyl)trimethylammonium bromide $(0.94 \mathrm{~g}$, $3.27 \mathrm{mmol})$ and $\mathrm{K}_{2} \mathrm{CO}_{3}(0.54 \mathrm{~g}, 3.92 \mathrm{mmol})$ were refluxed for $20 \mathrm{~h}$. The reaction was checked with TLC until compound C disappeared. The excess solvent was evaporated in a vacuum and the remaining product was extracted several times with chloroform $/ \mathrm{H}_{2} \mathrm{O}$. The chloroform phase was dried with anhydrous magnesium sulfate. The target product $(\mathbf{C N})$ was obtained as a white solid (yield: 90\%). ${ }^{1} \mathrm{H}-\mathrm{NMR}\left(400 \mathrm{MHz}, \mathrm{CDCl}_{3}\right.$ ): 1.17 (s, 18H, t-butyl), 1.52 (s, 18H, $t$-butyl), 2.02 (bs, 4H, $\left.\mathrm{CH}_{2}\right), 2.27-2.36$ (bs, $\left.8 \mathrm{H},-\mathrm{CH}_{2}\right), 3.56\left(\mathrm{~d}, 4 \mathrm{H}, \mathrm{J}=13.3 \mathrm{~Hz}, \mathrm{Ar}-\mathrm{CH}_{2}-\mathrm{Ar}\right), 3.69-3.73$ (s, 18H, N-CH $), 3.99$ (bs, $4 \mathrm{H},-$ $\left.\mathrm{CH}_{2}\right), 4.22$ (bs, $\left.4 \mathrm{H},-\mathrm{CH}_{2}\right), 4.44\left(\mathrm{~d}, 4 \mathrm{H}, J=13.3 \mathrm{~Hz}, \mathrm{Ar}-\mathrm{CH}_{2}-\mathrm{Ar}\right), 7.12(\mathrm{~s}, 4 \mathrm{H}, \mathrm{ArH}), 7.29(\mathrm{~s}, 4 \mathrm{H}, \mathrm{ArH}), 7.39(\mathrm{~s}, 2 \mathrm{H}$, ArOH). ${ }^{13} \mathrm{C}-\mathrm{NMR}\left(100 \mathrm{MHz}, \mathrm{CDCl}_{3}\right):$ 22.3, 22.8, 29.2, 31.2, 31.3, 36.5, 31.8, 34.0, 34.4, 52.7, 65.8, 76.2, 125.6, 126.0, $128.1,133.5,141.9,147.4,150.3,150.5$. 


\subsection{Cells and Cell Culture}

A-549 (human Lung cancer line), HeLa (human cervix cancer line) and healthy epithelial cell line, Hep-2 were obtained from ATCC (American Type Culture Collection). Cells were incubated with DMEM F-12K, EMEM and MEM mediums, respectively and supplemented with 10\% FBS (fetal bovine serum), antibiotics (100 U/mL penicillin and $100 \mu \mathrm{g} / \mathrm{mL}$ streptomycin) and $2 \mathrm{mM} \mathrm{L}$-glutamine at $37^{\circ} \mathrm{C}$ in a $5 \% \mathrm{CO}_{2}$ atmosphere and $95 \%$ humidity.

\subsection{Alamar Blue Cell Viability Assay}

Cell viability was determined by the Alamar Blue method (Invitrogen, Thermo Fischer Scientific, Waltham, MA, USA). Cells in the sub-culture stage were harvested from the flask by treatment with trypsin [0.05\% in PBS (pH 7.4) containing 0.02\% EDTA (Erdemir ve ark., 2021). The IC 50 value of compounds $\mathrm{CN}$ and CP were detected from the sigmoidal graph of cell inhibition, statistical analyzes were performed with GraphPad Prism software.

\section{RESULTS AND DISCUSSION}

The intent of current study was to synthesize antiproliferative agents from calixarene by containing cationic groups like 3-bromopropyl-triphenyl-phosphonium bromide and 5-bromopentyltrimethylammonium bromide (Figure 1). As depicted in Figure 1, Compound $\mathbf{C N}$ and $\mathbf{C P}$ were synthesized by reacting $p$-tert-butylcalix[4]arene with 3-bromopropyl-triphenyl-phosphonium bromide and 5bromopentyl-trimethylammonium bromide in acetone e for $20 \mathrm{~h}$ and $36 \mathrm{~h}$, respectively. The formation of $\mathbf{C N}$ was approved by the presence of specific bands at $1197 \mathrm{~cm}^{-1}$ for C-N, $3350 \mathrm{~cm}^{-1}$ for Ar-OH in the FTIR spectra (Fig. 2). The formation of $\mathbf{C P}$ was confirmed by the appearance of the characteristic Ar-P bands at about $1475 \mathrm{~cm}^{-1}$ and Ar-OH at $3341 \mathrm{~cm}^{-1}$ in the FTIR spectra (Fig. 3).

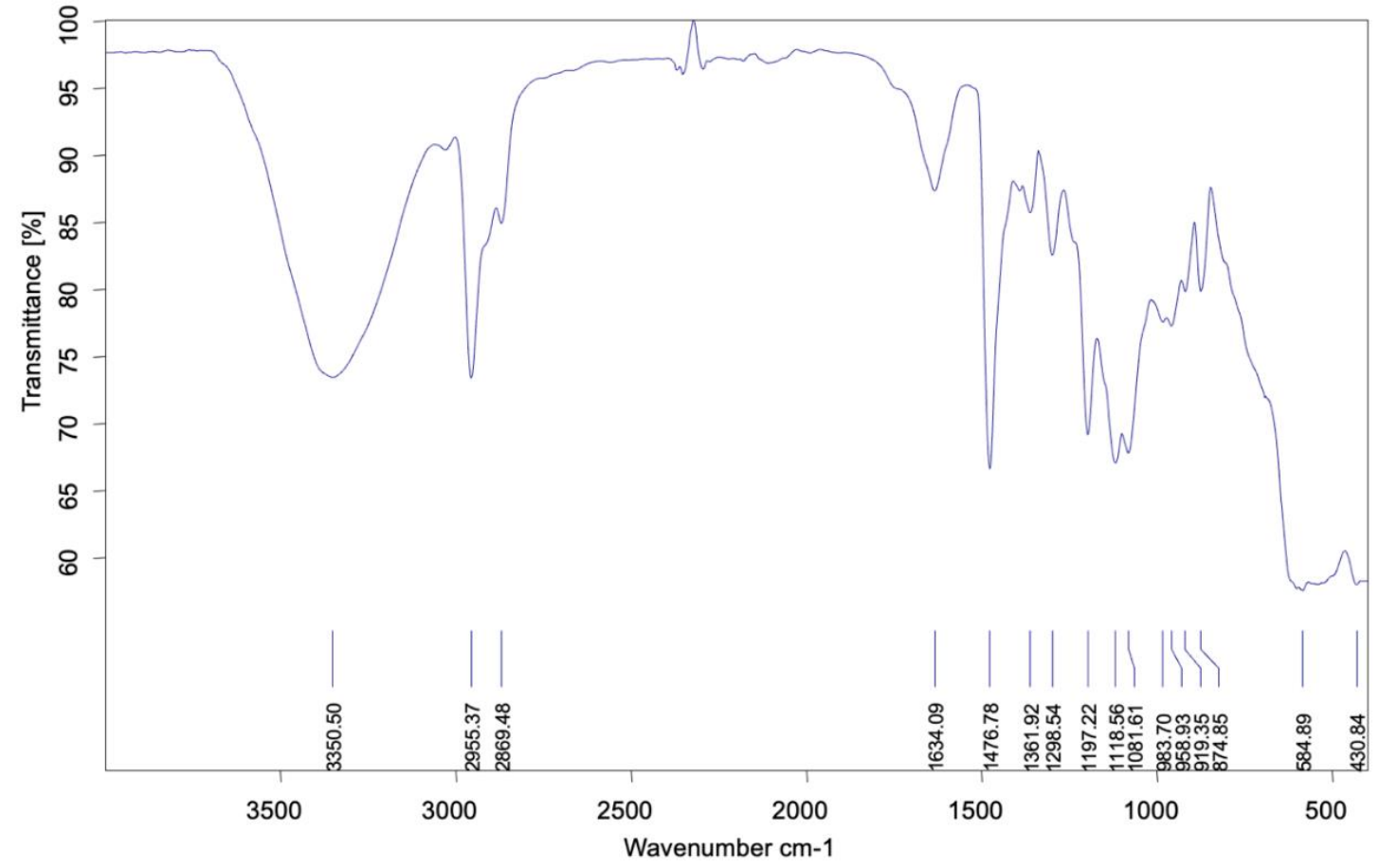

Figure 2. FTIR spectrum of compound $\mathbf{C N}$ 


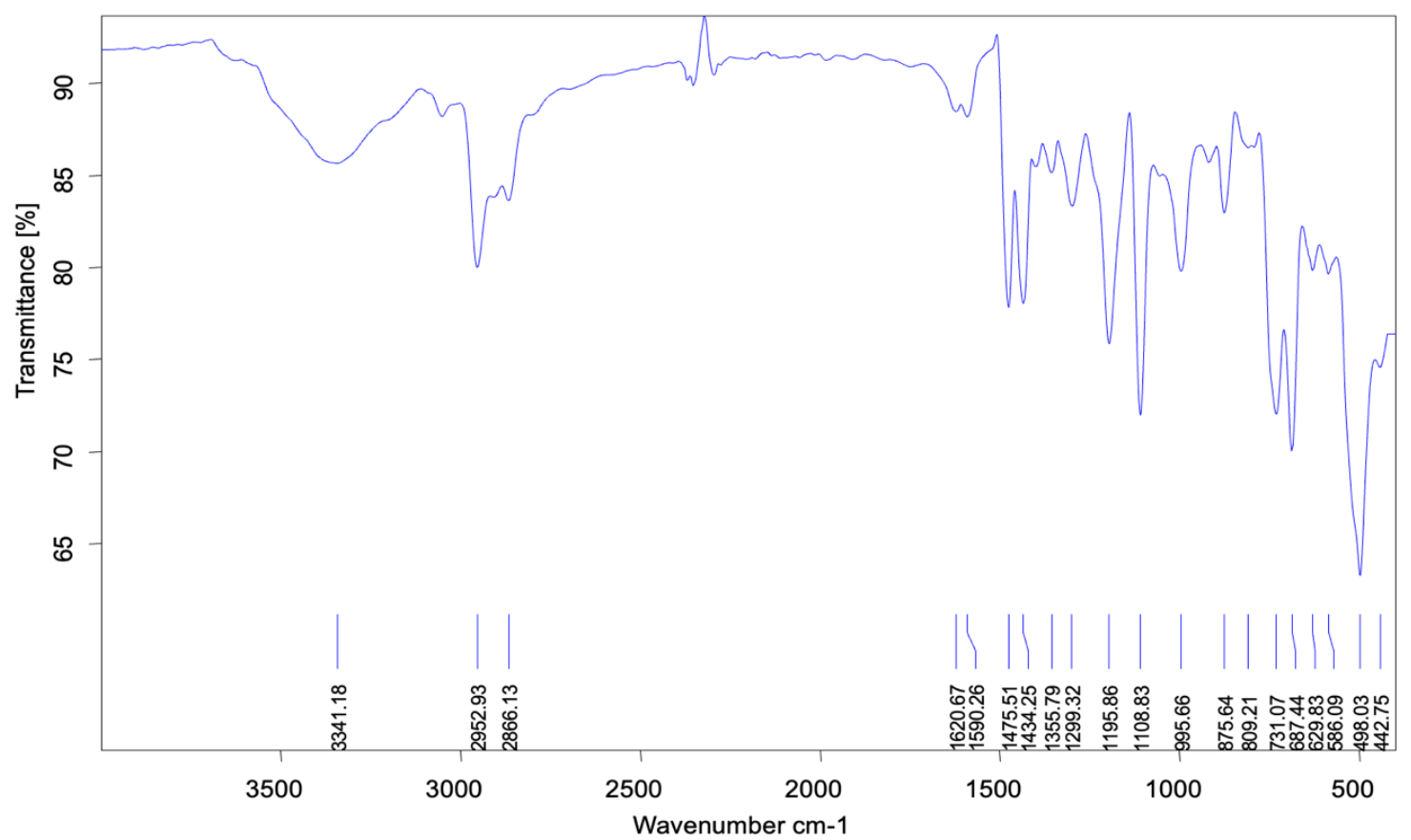

Figure 3. FTIR spectrum of compound CP

According to ${ }^{1} \mathrm{H}$ NMR spectra, the structure of $\mathbf{C N}$ was approved by the presence of $-\mathrm{CH}_{2}$ signals between 2.22 and $4.44 \mathrm{ppm}$, the existence of two p-tert butyl signals $\left(-\mathrm{C}\left(\mathrm{CH}_{3}\right)_{3}\right)$ at $1.17 \mathrm{ppm}$ and $1.52 \mathrm{ppm}$. In addition, the presence of the $\mathrm{N}-\mathrm{CH}_{3}$ signals at $3.75 \mathrm{ppm}$, ArH signals at $7.01 \mathrm{ppm}$ and $7.29 \mathrm{ppm}$ proved the successful synthesis of $\mathrm{CN}$ (Fig. 4).

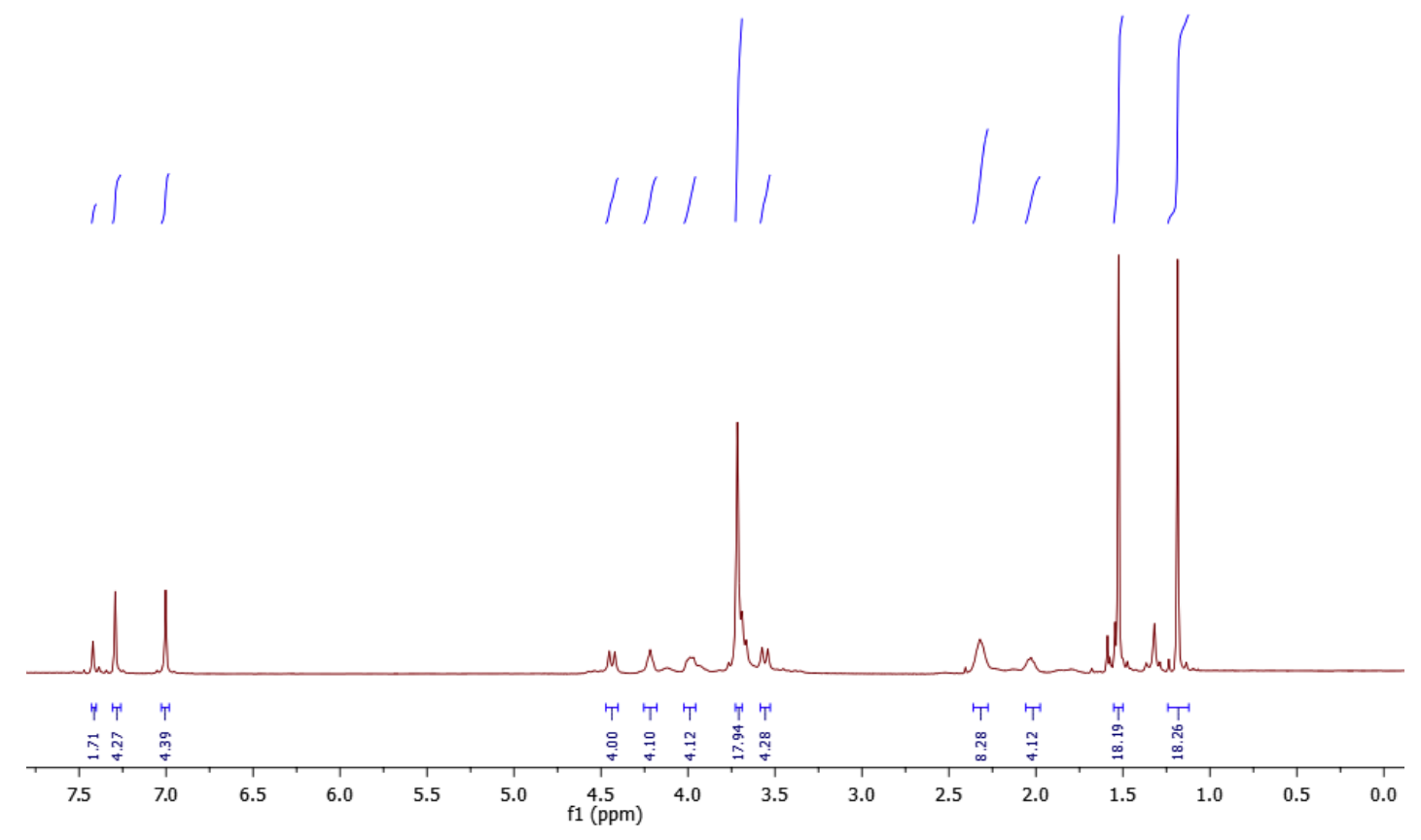

Figure 4. ${ }^{1} \mathrm{H}$ NMR spectrum of compound $\mathrm{CN}$ 


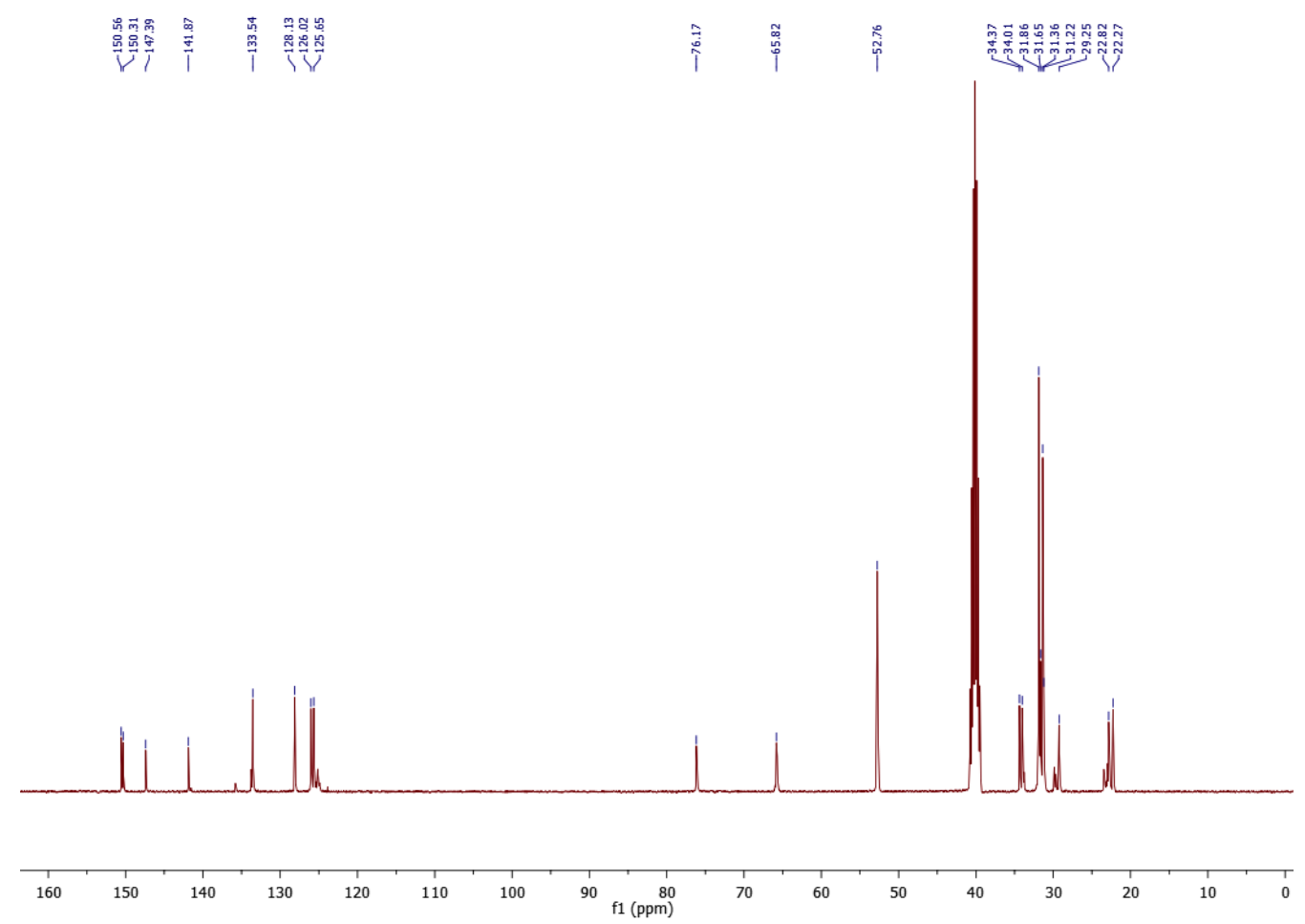

Figure 5. ${ }^{13} \mathrm{C}$ NMR spectrum of compound $\mathrm{CN}$

The existence of the peaks at $1.08 \mathrm{ppm}$ and $1.54 \mathrm{ppm}$ for p-tert-butyl groups $(-\mathrm{C}(\mathrm{CH} 3) 3)$, the peaks between $2.53 \mathrm{ppm}$ and $4.47 \mathrm{ppm}$ for $-\mathrm{CH}_{2}$ groups, and the presence of new $\mathrm{ArH}$ protons from 7.91 to $8.14 \mathrm{ppm}$ was confirmed the successful synthesis of $\mathbf{C P}$ (Fig. 6).

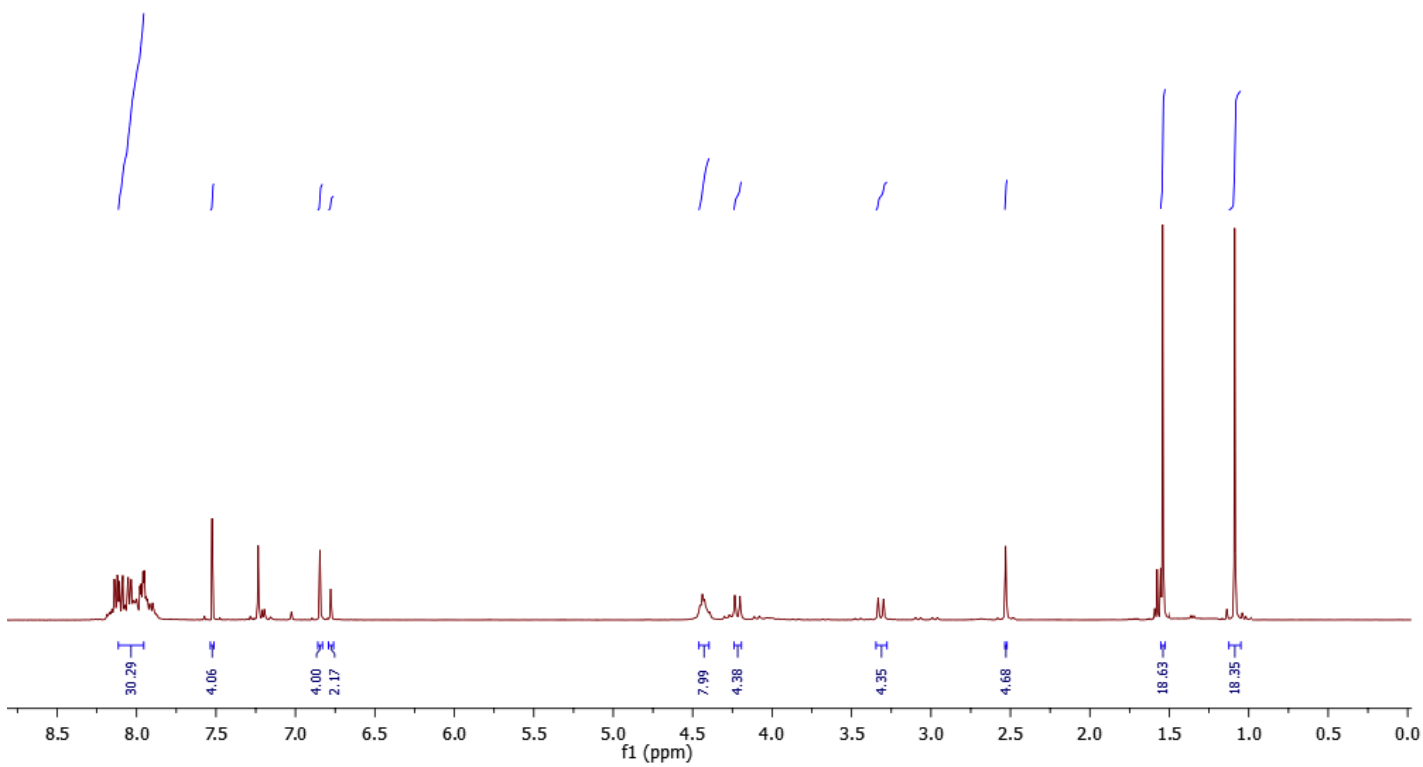

Figure 6. ${ }^{1} \mathrm{H}$ NMR spectrum of compound $\mathrm{CP}$ 


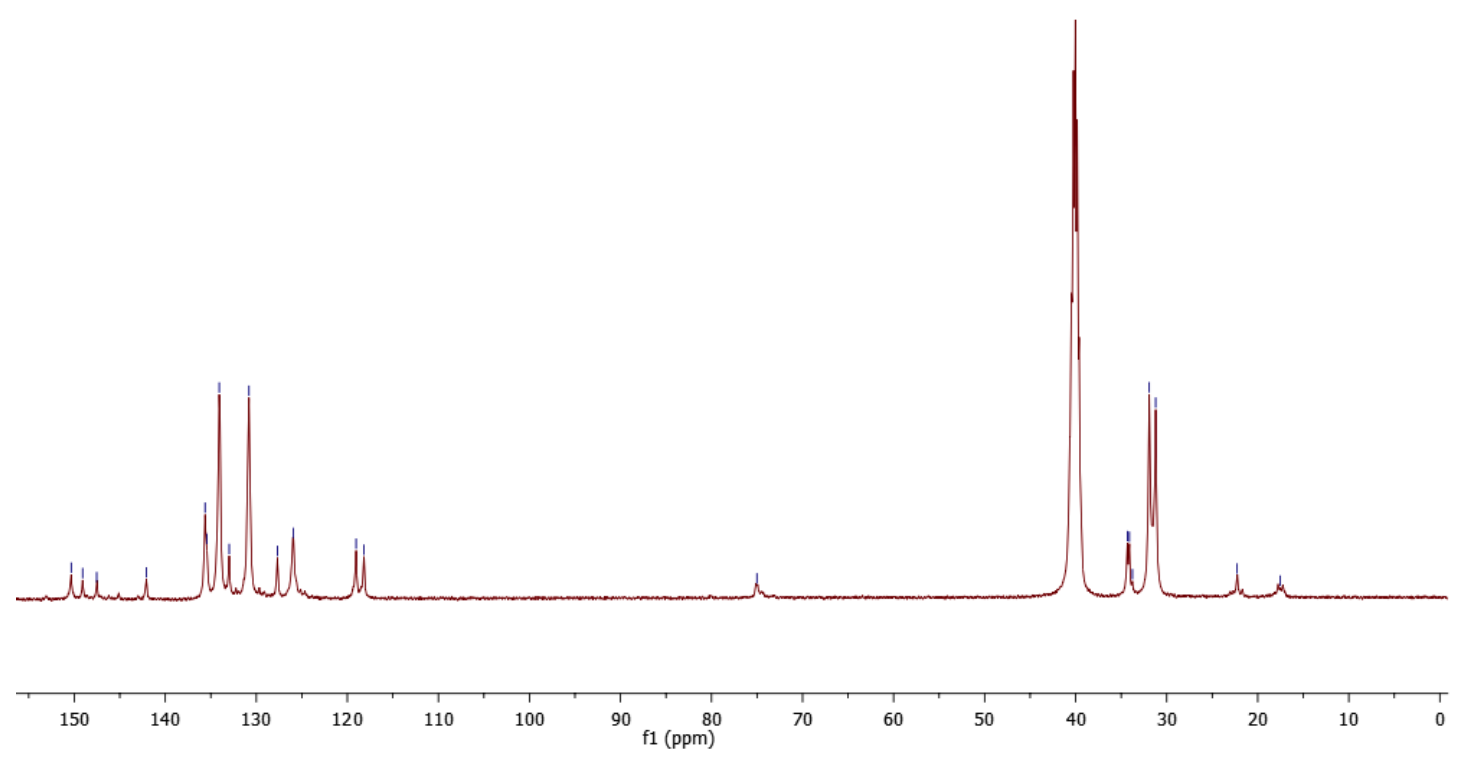

Figure 7. ${ }^{13} \mathrm{C}$ NMR spectrum of compound $\mathbf{C P}$

\subsection{Cytotoxicity study of cationic calix[4]arene Derivatives (CN and CP)}

In vitro cytotoxicity of $\mathbf{C N}$ and $\mathbf{C P}$ compounds was examined at various concentrations to determine their cytotoxic effects on the proliferation and viability of lung cancer cell line A549, cervix cancer cell line HeLa and epithelial cell line Hep-2 cells using the Alamar blue assay (Figure 8). $\mathbf{C N}$ and $\mathbf{C P}$ compounds inhibited the proliferation and viability of the lung and cervix cancer cell lines in a dose-dependent manner (Table 1). As shown in Table 1, compounds $\mathbf{C N}$ and $\mathbf{C P}$ were found to show high cytotoxic effect over human lung cancer cell (A549) and human cervix cancer cell (HeLa) and had IC 50 values of $13.42 \mu \mathrm{M}$ for $\mathrm{CN}$ and $17.05 \mu \mathrm{M}$ for $\mathbf{C P}$, respectively (Figure 9). In addition, $\mathbf{C N}$ and $\mathbf{C P}$ did not have cytotoxic effect on human epithelial cells (Hep-2) and their $\mathrm{IC}_{50}$ values were found to be $162.71 \mu \mathrm{M}$ and $>200 \mu \mathrm{M}$, respectively. 
Table 1. IC 50 values $(0-200 \mu \mathrm{M})$ of cationic calix[4]arenes on different cells

\begin{tabular}{cccc}
\hline & Hep-2 & A549 & HeLa \\
\hline CN & $>200$ & 13.42 & 28.96 \\
CP & 162.71 & 22.94 & 17.05 \\
3a* & -- & 89 & 100 \\
3d $^{*}$ & -- & 16 & 95 \\
\hline
\end{tabular}

$\left.{ }^{*}\right)$ Ref. (An et al., 2016)

a)

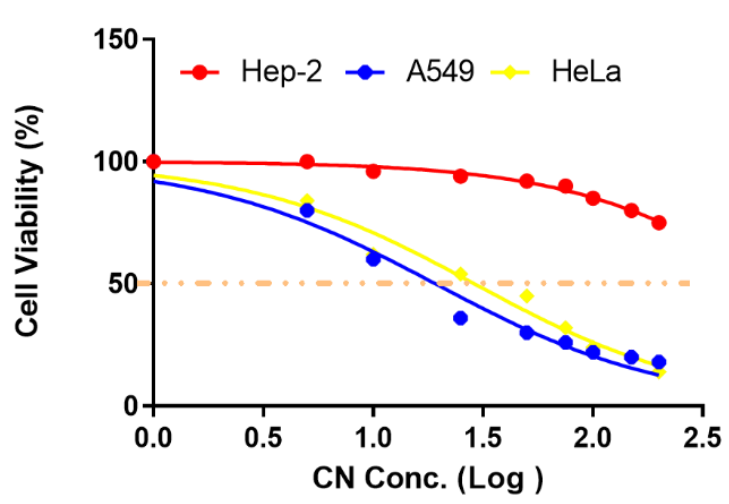

b)

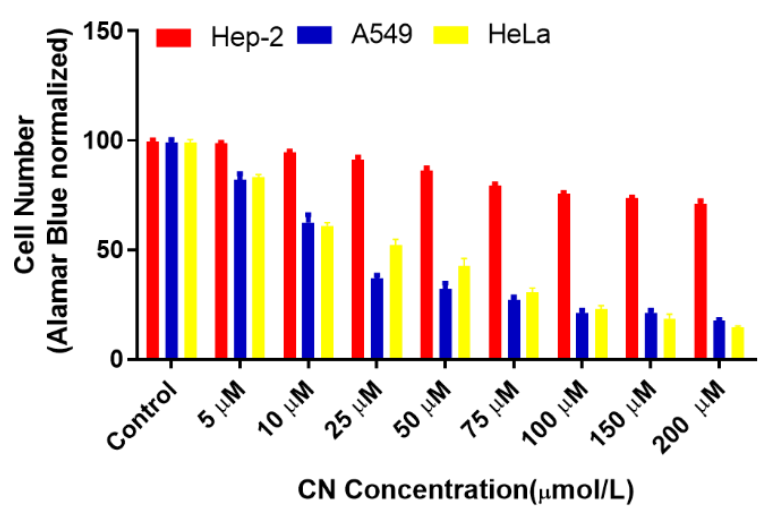

Figure 8. Influence of compound $\mathbf{C N}$ on the viability of A549, HeLa and Hep-2 cells. a) Alamar Blue test was utilized to analyze cytotoxicity. It was incubated for 48 hours with different concentrations in the range of 0 $200 \mu$ M. b) IC50 value of A549 and Hep-2 cells.

a)

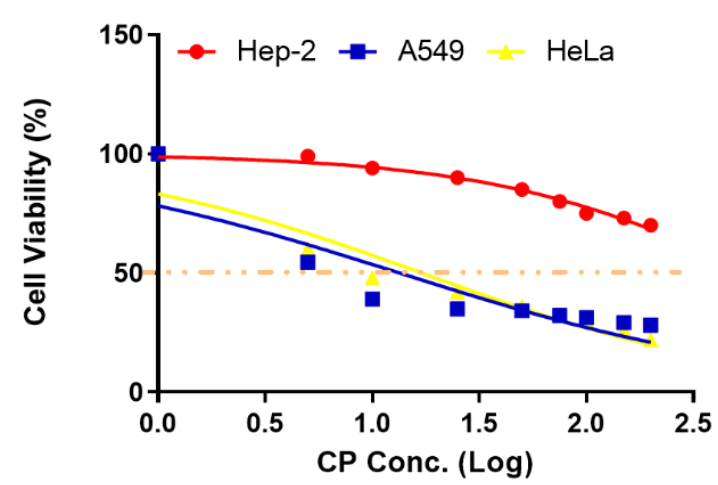

b)

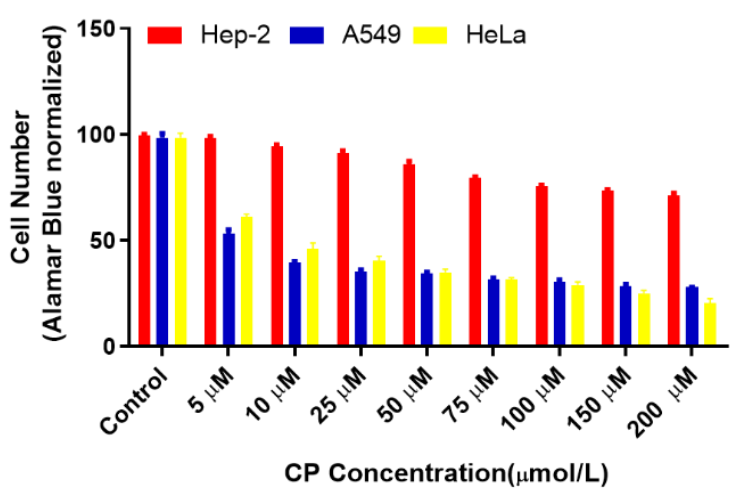

Figure 9. Influence of compound CN on the viability of A549, HeLa and Hep-2 cells. a) Alamar Blue test was utilized to analyze cytotoxicity. It was incubated for 48 hours with different concentrations in the range of 0 $200 \mu$ M. b) IC 50 value of A549 and Hep-2 cells. 


\section{CONCLUSION}

In summary, after successful synthesis of two cationic calixarene derivatives, their antitumor properties were evaluated. 5-Bromopentyl-trimethylammonium bromide derivative $(\mathbf{C N})$ showed the highest toxicity against human A549 cell line $(13.42 \mu \mathrm{M})$ and 3-bromopropyl-triphenyl- phosphonium bromide derivative (CP) showed the highest toxicity against human HeLa cell line $(17.05 \mu \mathrm{M})$. Results show that $\mathbf{C N}$ and $\mathbf{C P}$ are desirable antiproliferative agents since no cytotoxic effects have been observed on healthy epithelium cells. Hope this study will find its applicability in the field of the drug industry.

\section{CONFLICT OF INTEREST}

The authors declare no conflict of interest.

\section{ACKNOWLEDGMENTS}

We thank the Selcuk University, Konya (SUBAP-Grant Number: 21401034) for the financial support of this work.

\section{REFERENCES}

Akceylan, E., Erdermir, S., Ozcelik, E., Tabakci, B., 2021, “Removal of some phenolic pollutions from aqueous solutions by magnetic nanoparticles containing imidazole-derivatized calix[4]arene", Konya Journal of Engineering Sciences, 9 (2), 442-454.

An, L., Han, L.-L., Zheng, Y.-G., Peng, X.-N., Xue, Y.-S., Gu, X.-K., Sun, J. and Yan, C.-G., 2016, "Synthesis, Xray crystal structure and anti-tumor activity of calix[n]arene polyhydroxyamine derivatives", European Journal of Medicinal Chemistry, 123, 21-30.

An, L., Wang, C., Han, L., Liu, J., Huang, T., Zheng, Y., Yan, C. and Sun, J., 2019, "Structural Design, Synthesis, and Preliminary Biological Evaluation of Novel Dihomooxacalix[4]arene-Based Anti-tumor Agents", Frontiers in chemistry, 7, 856.

An, L., Wang, C., Zheng, Y.-G., Liu, J.-D. and Huang, T.-H., 2021, "Design, synthesis and evaluation of calix[4]arene-based carbonyl amide derivatives with antitumor activities", European Journal of Medicinal Chemistry, 210, 112984.

Cengel, F. and Farabi, T., 2021, "Removal of p-nitrophenol from aqueous solutions by calixarene based graphene oxide", Konya Journal of Engineering Sciences, 9, 79-90.

Consoli, G. M. L., Granata, G., Fragassi, G., Grossi, M., Sallese, M. and Geraci, C., 2015, "Design and synthesis of a multivalent fluorescent folate-calix[4]arene conjugate: cancer cell penetration and intracellular localization", Organic \& biomolecular chemistry, 13 (11), 3298-3307.

de Fátima, Â., Fernandes, S. A. and Sabino, A. A., 2009, "Calixarenes as new platforms for drug design", Current Drug Discovery Technologies, 6 (2), 151-170.

Dings, R. P., Levine, J. I., Brown, S. G., Astorgues-Xerri, L., MacDonald, J. R., Hoye, T. R., Raymond, E. and Mayo, K. H., 2013, "Polycationic calixarene PTX013, a potent cytotoxic agent against tumors and drug resistant cancer", Investigational new drugs, 31 (5), 1142-1150.

Erdemir, S., Oguz, M. and Malkondu, S., 2021, "A NIR fluorescent sensor based on thiazoline-isophorone with low cytotoxicity in living cells for $\mathrm{Hg}^{2+}$ detection through ICT associated hydrogen bonding effect", Analytica Chimica Acta, 339353. 
Geraci, C., Consoli, G. M., Galante, E., Bousquet, E., Pappalardo, M. and Spadaro, A., 2008, "Calix [4] arene decorated with four Tn antigen glycomimetic units and P3CS immunoadjuvant: synthesis, characterization, and anticancer immunological evaluation", Bioconjugate chemistry, 19 (3), 751-758.

Läppchen, T., Dings, R. P., Rossin, R., Simon, J. F., Visser, T. J., Bakker, M., Walhe, P., Van Mourik, T., Donato, K. and Van Beijnum, J. R., 2015, "Novel analogs of antitumor agent calixarene 0118: Synthesis, cytotoxicity, click labeling with 2-[18F] fluoroethylazide, and in vivo evaluation", European Journal of Medicinal Chemistry, 89, 279-295.

Naseer, M. M., Ahmed, M. and Hameed, S., 2017, "Functionalized calix[4]arenes as potential therapeutic agents," Chemical biology \& drug design, 89 (2), 243-256.

Nimse, S. B. and Kim, T., 2013, "Biological applications of functionalized calixarenes," Chemical Society Reviews, $42(1), 366-386$.

Oguz, M., Gul, A., Karakurt, S. and Yilmaz, M., 2020, "Synthesis and evaluation of the antitumor activity of Calix[4]arene L-proline derivatives", Bioorganic chemistry, 94, 103207.

Oguz, M., Gul, A., Karakurt, S. and Yilmaz, M., 2020, "Synthesis of New Picolylamine Bearing Calix[8]arene Derivatives as Antiproliferative Agents for Colorectal Carcinoma", ChemistrySelect, 5 (39), 1225012254.

Oguz, M., Kalay, E., Akocak, S., Nocentini, A., Lolak, N., Boga, M., Yilmaz, M. and Supuran, C. T., 2020, "Synthesis of calix[4]azacrown substituted sulphonamides with antioxidant, acetylcholinesterase, butyrylcholinesterase, tyrosinase and carbonic anhydrase inhibitory action", Journal of enzyme inhibition and medicinal chemistry, 35 (1), 1215-1223.

Oguz, M., Alizada, M., Gul, A., Kursunlu, A. N. and Yilmaz, M., 2021, "A basket-type fluorescent sensor based calix[4]azacrown ether for multi-analytes: Practicability in living cells and real sample", Microchemical Journal, 167, 106279.

Ozcelik, E., Farabi, T. and Tabakci, M., 2019, "Sensing of p-nitrophenol in aqueous media on qcm sensor coated with calixarene derivative immobilized merrifield resin", Konya Journal of Engineering Sciences, 7 (3), 595-603.

Pur, F. N., 2016, "Calixdrugs: calixarene-based clusters of established therapeutic drug agents", Molecular diversity, 20 (3), 781-787.

Rego, Y. F., da Silva, C. M., da Silva, D. L., da Silva, J. G., Ruiz, A. L. T., de Carvalho, J. E., Fernandes, S. A. and de Fatima, A., 2019, "Phthalazine-triones: Calix[4]arene-assisted synthesis using green solvents and their anticancer activities against human cancer cells", Arabian journal of chemistry, 12 (8), 40654073.

Rodik, R. V., Boyko, V. I. and Kalchenko, V. I., 2009, "Calixarenes in bio-medical researches", Current Medicinal Chemistry, 16 (13), 1630-1655.

Rouge, P., Pires, V. S., Gaboriau, F., Dassonville-Klimpt, A., Guillon, J., Nascimento, S. D., Leger, J.-M., Lescoat, G. and Sonnet, P., 2010, "Antiproliferative effect on HepaRG cell cultures of new calix[4]arenes", Journal of enzyme inhibition and medicinal chemistry, 25 (2), 216-227.

Saluja, V. and Sekhon, B. S., 2013, "Calixarenes and cucurbiturils: pharmaceutial and biomedical applications", Journal of Pharmaceutical Education and Research, 4 (1), 16.

Santos, D., Medeiros-Silva, J., Cegonho, S., Alves, E., Ramilo-Gomes, F., Santos, A. O., Silvestre, S. and Cruz, C., 2015, "Cell proliferation effects of calix[4]arene derivatives", Tetrahedron, 71 (40), 7593-7599.

Sayin, S. and Yilmaz, M., 2017, "Synthesis of environmentally friendly, efficient and highly recyclable Lewis acid-type calix[4]arene catalysts containing flexible or bulky groups for the Mannich reaction", RSC advances, 7 (18), 10748-10756.

Siegel, R. L., Miller, K. D. and Jemal, A., 2019, "Cancer statistics, 2019", CA: A Cancer Journal for Clinicians, 69 (1), 7-34. 
Yilmaz, B., Bayrac, A. T. and Bayrakci, M., 2020, "Evaluation of anticancer activities of novel facile synthesized calix[n]arene sulfonamide analogs", Applied biochemistry and biotechnology, 190 (4), 1484-1497.

Yousaf, A., Abd Hamid, S., Bunnori, N. M. and Ishola, A., 2015, "Applications of calixarenes in cancer chemotherapy: facts and perspectives", Drug design, development and therapy, 9, 2831.

Zhou, J., Rao, L., Yu, G., Cook, T. R., Chen, X. and Huang, F., 2021, "Supramolecular cancer nanotheranostics", Chemical Society Reviews, 50 (4), 2839-2891. 